\title{
Determination of Caregiver Burden and Social Support Levels among Caregivers Providing Care for Patients Hospitalized in Palliative Care Clinics
}

\author{
Papatya Karakurt ${ }^{1^{*}}\left(\mathbb{D}\right.$, Sevinç Köse Tuncer ${ }^{1}$ (D), Nadire Yildiz Çiltaş ${ }^{2}$ (D), Mehmet Doğan² ${ }^{2}$ (D)
}

\begin{abstract}
Providing care to someone with a chronic disease requires being physically, emotionally, and mentally energetic. In particular, the presence of a patient with a disease that requires palliative care changes daily activities and routines, increases responsibilities of those who take the responsibility for patient's care and changes the roles in the family.

The objective of this study was to determine the care burden and social support levels among the caregivers providing care for patients hospitalized in palliative care clinics.

Materials and Methods. The population of this descriptive and correlational study consisted of caregivers taking care of patients treated at the Palliative Care Clinic of Training and Research Hospital between May and October 2018; the sample consisted of 73 caregivers who volunteered to join the study and were open to communication. Data were collected by questioning patients and their caregivers about their sociodemographic characteristics, using the Caregiver Burden Scale and the Multidimensional Scale of Perceived Social Support. Data analysis included percentages, the Kruskal-Wallis test, the Mann-Whitney U test, and the Spearman's Correlation Coefficient.

Results. The average caregivers' age was $45.44 \pm 13.76$ years; $75.3 \%$ of caregivers were females, $30.1 \%$ of caregivers were literate or had primary school degrees. Caregiver's gender and educational levels were found not to affect caregiving and social support levels; however, the economic status affected caregiving and social support levels. There was a reverse correlation between the caregiver burden and their social support levels.

Conclusions. With increased caregiver burden, their social support level decreased. Nurses caring for patients in palliative care clinics will benefit from educating and supporting caregivers about clinic and home care; it will result in a positive level of social support for both caregivers and patients receiving care.
\end{abstract}

Keywords

Caregivers; Care Burden; Palliative Care; Social Support; Nursing

${ }^{1}$ Faculty of Health Sciences, Erzincan BinaliYıldırım University, Erzincan, Turkey

${ }^{2}$ Ministry of Health-Erzincan Binali Yıldırım University Mengücek Gazi Training and Research Hospital, Erzincan, Turkey

${ }^{\star}$ Corresponding author: papatyademirci@hotmail.com

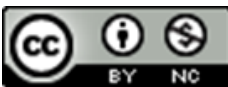

Copyright @Papatya Karakurt, Sevinç Köse Tuncer, Nadire Yildiz Çiltaş, Mehmet Doğan, 2020

\section{Problem statement and analysis of the latest research}

Palliative care keeps patients as active as possible while they live and supports families in coping with the disease process. In this regard, palliative care includes both patients and their relatives. Providing care to an individual with a chronic disease requires being physically, emotionally, and mentally energetic. In particular, the presence of a patient with a disease that requires palliative care changes daily activities and routines, increases responsibilities of those who take care of the patient, and changes the roles in the family. A patient's being at a stage of requiring palliative care could cause family members to experience negative physical, psychological, and social effects [1-3]. Therefore, the caregiver could bring more difficulties and burden for patient's relatives who experience depressive symptoms such as fatigue and sleep problems [4].

Since the caregiver burden has significant effects on maintaining the patient's well-being, health professionals should pay special attention to caregivers [5]. 


\section{Determination of Caregiver Burden and Social Support Levels among Caregivers Providing Care for Patients \\ Hospitalized in Palliative Care Clinics - 2/7}

Increased prevalence of chronic diseases in developed countries is a serious problem for family members. Chronic diseases and their treatment have negative effects on the physical and emotional well-being of both patients and family members, especially caregivers. With increasing acceptance of palliative care for end-of-life care, the need for physical, as well as psycho-social care of patients and family members is growing. Patients and caregivers' emotional and social support components were secondary to the physical care and treatment in palliative care [6].

The process of palliative care is based on teamwork. This team includes health professionals and patients, as well as caregivers. In palliative care, it is important to support both the patients and caregivers and continue to provide the caregivers with support in the grieving process after the patient's death [3]. Nurses should provide the caregivers with appropriate support to ensure that caregivers are aware that maintaining the patient's care should not threaten caregivers' physical and psychological health and there is less burden to experience [7]. The caregiver should certainly be provided with physical and emotional support [8]. Caregivers might fail to manage the effects of the care burden on themselves and experience emotions such as helplessness, guilt, fear, and social isolation. The negative effects of the burden vary from person to person, as well as across societies. It is important for health professionals to evaluate the risk groups and support caregivers when it is necessary [1]. A systematic review of caregivers reported that biopsychosocial and moral support given to caregivers could decrease the patients' problems caused by their disease, and an effective coping method could decrease caregiver stress and burden, and help the caregiver to adapt [9]. Various studies involving caregivers conducted in our country showed that the caregiver burden referred to their patients' care was at a high/moderate level [10-14]; however, their social support levels were high/low [15-17].

In a mixed patient population, the caregiver burden could be effectively facilitated through palliative care services including primarily cancer patients. By giving multidimensional care, nurses could substantially increase the quality of palliative care. Palliative care includes religious/moral beliefs, sufficient support for coping with own emotions, emotions after considering the probability of death, referring the family to psychological support services for emotional/moral needs, supporting family's self-sufficiency and weakness, strong confidence in when and what to do for the patient [18]. While these nursing care practices decrease the caregiver burden, they increase their social support levels as well.

Therefore, the objective of this research was to identify the care burden and social support levels among the caregivers providing care for patients hospitalized in palliative care clinics.

\section{Materials and Methods}

This descriptive study was conducted at the Palliative Care Clinic of Training and Research Hospital. This research took place in a province in the eastern part of Turkey. The target population of the study included the patients who were hospitalized in the Palliative Care Clinic between May and October 2018 and their caregivers, and the sample consisted of 73 caregivers and their patients who volunteered to participate in the study and who were open to communication. All the caregivers included in the study were family members or close relatives. The study involved 73 patients and 73 caregivers. Data were collected through the Sociodemographic Form that included the information on patients and caregivers' sociodemographic characteristics, the Caregiver Burden Inventory (CBI), and the Multidimensional Scale of Perceived Social Support (MSPSS).

\section{Sociodemographic Form}

The form consists of 11 questions about the patients and caregivers' sociodemographic characteristics and the caregiver role (age, gender, education level, income level, duration of caregiving, and duration of being bedridden).

\section{Zarit Caregiver Burden Inventory}

The Zarit Caregiver Burden Inventory was developed by Zarit, Reeverveve Bach-Peterson in 1980 [19]. Turkish adaptation of the inventory was done by Inci et al. in 2006. The scale aims to measure the level of difficulties experienced by caregivers. The scale could be filled either by the caregiver or the researcher who asks the questions on the scale. The scale consists of 22 statements that identify the effect of caregiving on the individual's life. The scores range between 0 and 88. The items in the scale usually refer to social and emotional dimensions, and higher scores indicate higher levels of the problems experienced [20]. The scores indicate the following results: 0-20 points - "little or no burden"; 21-40 points -"mild-to-moderate burden"; 41-60 points - "moderateto-severe burden"; 61-88 points - "severe burden". Cronbach's alpha value of the scale was reported to be 0.95 [20]. This study found the Cronbach's alpha reliability coefficient value as 0.89 .

\section{MSPSS}

The MSPSS was developed by Zimet, Dahlem, Zimet, and Farley (1988) [21]. The scale enables subjective assessing the sufficiency of the support received from three different sources (family, friends, significant others). While the scores of the sub-scales range between 4 and 28, the total score of the scale ranges between 12 and 84 . Higher scores indicate higher levels of perceived social support. Turkish reliability and validity of the scale were performed by Eker and Arkar in healthy subjects and patients [22]. In this study, Cronbach's alpha reliability of the scale was 0.95 .

\section{Data Analysis}

Data were analyzed on a computer using the Statistical Package for the Social Sciences (SPSS) (IBM Corp., Armonk, NY, USA) version 21.0. Descriptive statistics were summarized as the mean and standard deviation for continuous variables 


\section{Determination of Caregiver Burden and Social Support Levels among Caregivers Providing Care for Patients \\ Hospitalized in Palliative Care Clinics - 3/7}

in summarizing the data obtained from the study. Categorical variables were summarized as numbers and percentages. Data analysis included the Kruskal-Wallis test, the MannWhitney U test, and the Spearman's Correlation Coefficient. $\mathrm{P}$-value was taken $\mathrm{p}<0.05$ for statistical significance.

\section{Ethical Considerations}

After written permission was obtained from the Human Research Ethics Committee of Erzincan Binali Y1ldırım University (Minutes No. 03/01 of March 29, 2018) and the Faculty of Health Sciences of Erzincan University, written permission was obtained from the institution where the study was conducted.

\section{Informed Consent}

The patients' caregivers were informed about the purpose and benefits of the study. All participants gave informed consent for the research, and their anonymity was preserved.

\section{Results}

Of all the caregivers involved in the study, $31.5 \%$ of caregivers were at the age of 39 years and younger, $75.3 \%$ of caregivers were females, $30.1 \%$ of caregivers were literate or primary school graduates, $39.7 \%$ of caregivers had income equal to their expenses, and 54.8\% of caregivers had been providing care to their patient for 6 months and more. The average age of the patients was $66.59 \pm 19.90$ years. Of all the participating patients, $57.5 \%$ of patients were females, and $69.9 \%$ of patients had been bedridden for 1-3 years.

The average CBI score was $46.33 \pm 16.55$, and their mean score of total social support was $46.19 \pm 23.40$ (Table 1).

Table 1. CBI and MSPSS mean scores $(\mathrm{n}=73)$.

\begin{tabular}{lc}
\hline Scales & $\mathrm{X} \pm \mathrm{SD}$ \\
\hline CBI & $46.33 \pm 16.55$ \\
MSPSS & \\
Family & $17.99 \pm 9.05$ \\
Friends & $12.82 \pm 9.03$ \\
Significant Others & $15.38 \pm 9.29$ \\
Total Social Support & $46.19 \pm 23.40$ \\
\hline Notes: X
\end{tabular}

Notes: $\mathrm{X}=$ Mean; $\mathrm{SD}=$ Standard Deviation.

No significant differences were found between the CBI and MSPSS mean scores according to caregivers' age, gender, and duration of caregiving (Table 2).

A significant difference was found between the CBI and MSPSS total scores and family and significant other subscales depending on the caregivers' education level. The average caregiver burden experienced by people with higher education was $32.83 \pm 8.62$, and it was found to be the lowest as compared to the other groups. The average social support score was $59.25 \pm 19.66$ and it was found to be the highest.

A significant difference was found between the CBI and MSPSS scales and sub-scales depending on the caregivers' perceived income level. The average caregiver burden experienced by people with high income was $38.32 \pm 16.46$, which was found to be the lowest as compared to the other groups. The average social support score was $65.79 \pm 18.96$ and it was found to be the highest one.

Although the duration of being bedridden did not have any effects on caregiver burden, the total MSPSS score was found to have an impact on family and significant other sub-scales (Table 2).

A negative, moderate relationship was found between the caregiver burden and social support levels (Table 3).

\section{Discussion}

The caregiver burden experienced by people caring for patients who are hospitalized in palliative care clinics is considered to be increasing. Therefore, caregivers should be provided with social support. The care burden and social support levels among participating caregivers were above average. Some studies involving the caregivers caring for patients who were hospitalized in palliative care units reported that the patients' health status increased the caregivers' burden $[23,24]$ similar to the present study; some other studies reported that the care burden was above average [10,13]. In the study involving caregivers providing care of patients with cancer, the care burden was low [25]. In contrast to the findings of the present study, some studies reported low/high social support levels experienced by caregivers [15-17, 26]. The findings similar to this study were obtained by other studies, according to which, the caregivers experienced a certain level of burden. In this regard, caregiver's experiences (their duties and consequences) and needs should be identified by health professionals and appropriate support services should be given. In this way, high-quality care could be provided, caregiver's satisfaction could be increased, and the care burden could be decreased [27]. Considering the palliative care recipients' health status, the increase in the caregiver burden is expected. In addition, higher mean scores of family and significant other sub-scales indicated that caregivers inevitably received support from both family and nurses.

Caregivers' sociodemographic characteristics such as age, gender, and duration of caregiving were found not to affect the care burden and social support levels. The findings similar to this study were obtained by other studies involving caregivers, according to which, there was no significant difference in the caregiver burden depending on caregivers' age, gender, and duration of caregiving [13,28]. A study conducted by Küçükoğlu (2019) found that there was a significant difference in the caregiver burden depending on caregivers' gender and duration of caregiving [11]. A few studies involving caregivers showed that age, gender, and duration of caregiving demonstrated differences in affecting the caregiver burden $[10,29]$. These differences between the study findings could be associated with cultural differences of the societies and value judgments family members have. In addition, the caregiver burden is considered to increase or decrease de- 
Table 2. Comparison of the CBI and MSPSS mean scores according to Caregivers and Patients' Descriptive Characteristics $(n=73)$.

\begin{tabular}{|c|c|c|c|c|c|c|}
\hline Descriptive Features & Number $(\%)$ & $\begin{array}{l}\text { Caregiver } \\
\text { burden }\end{array}$ & Family & Friends & $\begin{array}{c}\text { Significant } \\
\text { Others }\end{array}$ & $\begin{array}{c}\text { Total Social } \\
\text { Support }\end{array}$ \\
\hline \multicolumn{7}{|l|}{ Age } \\
\hline 39 and below & $23(31.5)$ & $42.52 \pm 14.38$ & $18.26 \pm 8.22$ & $14.48 \pm 8.45$ & $14.61 \pm 8.38$ & $47.35 \pm 22.24$ \\
\hline $40-49$ & $19(26.0)$ & $48.74 \pm 17.04$ & $15.47 \pm 8.85$ & $13.74 \pm 9.75$ & $13.53 \pm 9.55$ & $42.74 \pm 24.45$ \\
\hline $50-59$ & $18(24.7)$ & $45.56 \pm 20.16$ & $20.28 \pm 9.86$ & $13.89 \pm 10.29$ & $17.44 \pm 10.27$ & $51.61 \pm 27.00$ \\
\hline 60 and over & $13(17.8)$ & $50.62 \pm 13.95$ & $18.00 \pm 9.72$ & $7.08 \pm 4.59$ & $16.62 \pm 9.39$ & $41.69 \pm 18.99$ \\
\hline $\mathrm{KW}^{*}$ & & 3.065 & 2.880 & 6.324 & 1.204 & 1.848 \\
\hline $\mathrm{p}$ & & 0.382 & 0.410 & 0.097 & 0.752 & 0.605 \\
\hline \multicolumn{7}{|l|}{ Gender } \\
\hline Female & $55(75.3)$ & $46.11 \pm 16.82$ & $18.84 \pm 8.93$ & $13.53 \pm 8.83$ & $16.09 \pm 9.43$ & $48.45 \pm 22.99$ \\
\hline Male & $18(24.7)$ & $47.00 \pm 16.14$ & $15.39 \pm 9.17$ & $10.67 \pm 9.52$ & $13.22 \pm 8.75$ & $39.28 \pm 23.92$ \\
\hline $\mathrm{U}^{* *}$ & & 475.500 & 377.500 & 394.500 & 402.500 & 381.500 \\
\hline $\mathrm{p}$ & & 0.803 & 0.128 & 0.191 & 0.232 & 0.146 \\
\hline \multicolumn{7}{|l|}{ Duration of Caregiving } \\
\hline$\leq 6$ months & $33(45.2)$ & $47.36 \pm 16.99$ & $19.18 \pm 9.29$ & $13.70 \pm 10.47$ & $16.88 \pm 10.06$ & $49.76 \pm 24.30$ \\
\hline$>6$ months & $40(54.8)$ & $45.48 \pm 16.33$ & $17.00 \pm 8.85$ & $12.10 \pm 7.70$ & $14.15 \pm 8.54$ & $43.25 \pm 22.51$ \\
\hline $\mathrm{U}^{* *}$ & & 591.500 & 576.000 & 654.500 & 559.500 & 585.500 \\
\hline $\mathrm{p}$ & & 0.448 & 0.346 & 0.951 & 0.260 & 0.260 \\
\hline \multicolumn{7}{|l|}{ Education Level } \\
\hline Illiterate & $7(9.6)$ & $60.00 \pm 14.19$ & $18.71 \pm 11.38$ & $10.29 \pm 6.29$ & $16.71 \pm 12.07$ & $45.71 \pm 28.99$ \\
\hline Literate/Primary School & $22(30.1)$ & $55.45 \pm 15.07$ & $15.73 \pm 9.66$ & $10.18 \pm 8.99$ & $13.27 \pm 10.11$ & $39.18 \pm 23.74$ \\
\hline Secondary School & $20(27.4)$ & $47.70 \pm 15.36$ & $15.35 \pm 8.88$ & $11.45 \pm 7.64$ & $11.60 \pm 7.78$ & $38.40 \pm 19.56$ \\
\hline High School & $24(32.9)$ & $32.83 \pm 8.62$ & $22.04 \pm 6.65$ & $17.13 \pm 9.65$ & $20.08 \pm 6.99$ & $59.25 \pm 19.66$ \\
\hline $\mathrm{KW}^{*}$ & & 29.698 & 7.912 & 7.677 & 10.520 & 11.850 \\
\hline $\mathrm{p}$ & & 0.000 & 0.048 & 0.053 & 0.015 & 0.008 \\
\hline \multicolumn{7}{|l|}{ Income Level } \\
\hline Income less than expenses & $25(34.2)$ & $58.04 \pm 13.42$ & $13.36 \pm 9.47$ & $9.16 \pm 8.19$ & $10.00 \pm 7.77$ & $32.52 \pm 20.74$ \\
\hline Income equal to expenses & $29(39.7)$ & $41.48 \pm 13.61$ & $17.93 \pm 7.67$ & $12.45 \pm 7.09$ & $14.76 \pm 8.37$ & $45.14 \pm 19.48$ \\
\hline Income more than expenses & $19(26.1)$ & $38.32 \pm 16.46$ & $24.16 \pm 6.83$ & $18.21 \pm 10.41$ & $23.42 \pm 6.83$ & $65.79 \pm 18.96$ \\
\hline $\mathrm{KW}^{*}$ & & 21.288 & 16.414 & 9.249 & 23.104 & 21.826 \\
\hline $\mathrm{p}$ & & 0.000 & 0.000 & 0.010 & 0.000 & 0.000 \\
\hline \multicolumn{7}{|l|}{ Duration of being bedridden } \\
\hline $1-3$ years & $51(69.9)$ & $43.49 \pm 16.01$ & $19.86 \pm 8.39$ & $13.41 \pm 8.95$ & $17.29 \pm 9.08$ & $50.57 \pm 22.51$ \\
\hline $4-8$ years & $18(24.7)$ & $54.67 \pm 16.35$ & $12.72 \pm 9.04$ & $12.56 \pm 9.87$ & $11.33 \pm 8.99$ & $36.61 \pm 24.46$ \\
\hline 9 years and over & $4(5.5)$ & $45.00 \pm 15.06$ & $17.75 \pm 10.21$ & $6.50 \pm 2.89$ & $9.25 \pm 5.56$ & $33.50 \pm 14.62$ \\
\hline $\mathrm{KW}^{*}$ & & 5.517 & 8.767 & 2.367 & 6.798 & 6.315 \\
\hline $\mathrm{p}$ & & 0.063 & 0.012 & 0.306 & 0.033 & 0.043 \\
\hline
\end{tabular}

Table 3. Relationship between caregivers' CBI and MSPSS mean scores $(n=73)$.

\begin{tabular}{lcc}
\hline \multirow{2}{*}{ Social Support Scale } & \multicolumn{2}{c}{ Caregiver Burden Scale } \\
& $\mathrm{r}^{*}$ & $\mathrm{p}^{* *}$ \\
\hline Family & -0.419 & 0.000 \\
Friends & -0.322 & 0.006 \\
Significant Others & -0.422 & 0.000 \\
Total Social Support & -0.450 & 0.000 \\
\hline
\end{tabular}

Notes: $\mathrm{r}^{*}-$ the Spearman Correlation; $\mathrm{p}^{* *}-\mathrm{p}<0.01$

pending on the factors such as nurses' contribution to the care process or support mechanism provided by the hospitals where the study was conducted, which could cause differences in the findings as well. According to Gündüz (2019), caregivers' age, gender, and duration of caregiving did not affect their social support levels [16]. Another study reported that the duration of providing care to patients did not affect social support level, which was consistent with the findings of the present study as well [17]. According to the study results, the variables such as gender, age, and duration of caregiving did not have any effects on the caregivers' need for social support, which might indicate that all caregivers should be assessed in terms of social support.

The caregivers' education level and perceived income level were found to affect the care burden and social support levels. According to other studies, there were no significant 
differences between the care burden depending on the caregivers' education level and perceived income level $[13,28]$. A few studies showed that there were no significant differences in the care burden depending on the caregivers' education level or perceived income level $[10,11,29]$. While the study reported a significant difference between the caregivers' income level and perceived social support level, the difference in the education level was reported to be insignificant. The results of the study conducted by Gündüz (2019) were consistent with the results of our study [16]. The difference in the caregivers' education and income level in the regions where the study was conducted was considered to cause this difference in the findings.

Although the duration of being bedridden did not have any effects on the caregiver burden, the level of social support did. The findings similar to this study were obtained by Tanrikulu (2019), who reported no difference between the patient's type of disability and the care burden [30]. The findings obtained by Biçak (2016) differed from those we obtained; according to this study, caregivers caring for cancer patients reported that factors such as disease duration and disease diagnosis did not affect patients and caregivers' social support levels [17]. The results showed that due to the value given to the patient, the duration of caregiving did not have any effects on the care burden; caregivers provided their patients with care under all conditions and did not perceive them as a burden. However, causes such as fatigue and lack of sleep were reported to cause burnout and increase the need for social support among caregivers. These results indicated the importance of nurses identifying caregivers' social support needs and supporting them.

A negative correlation was found between the caregiver burden and social support levels. The caregiver burden was found to increase as social support decreased. The findings similar to this study were obtained by Öner (2012), who found that the caregiver burden increased, and social support decreased [26]. Another study involving the caregivers caring for stroke patients revealed that the patients' relatives had a lack of knowledge of their social structure, and, therefore, their anxiety led to a serious burden among caregivers. The caregiver burden was reported to increase even more due to the uncertainty about the patient's recovery [18]. This case caused a decrease in the level of social support experienced by caregivers. Another study also reported that caregivers still experienced an objective burden associated with their roles [31]. Another study involving caregivers reported that both caregiver support and emotional support were associated with positive family relationships, namely the level of social support became higher as the family became more functional [32]. There was a significant decrease in the psychological well-being and the quality of life among caregivers receiving the nursing initiative called "Palliative Care Caregivers" [33]. This result is thought to have an impact on the care burden. High family support and nurses' activation of caregivers' social support systems and supporting them are considered to decrease the caregiver burden.

\section{Conclusions}

This study investigated the caregiver burden and social support level experienced by caregivers caring for patients treated at palliative care clinics and found that the caregivers perceived caregiving as a moderate-level burden, and their perceived social support levels were found to be above average. The caregiver burden was found to increase as their social support levels decreased.

\section{Prospects of Further Researches}

According to the results of the study, it is highly important for nurses to organize educational activities and increase home care services to prevent the negative effect of the caregiver burden on caregivers' social support levels. The initiatives on this issue are believed to have positive effects on both patients and patients' relatives. In addition, studies with a larger sample group are recommended to be carried out for the identification of the factors causing burden and having negative effects on social support levels.

\section{Acknowledgements}

In this study, we did not use any foundation. The authors express their gratitude to all patients who took part in the study and thank the clerical staff of the clinic where these data were gathered.

\section{Conflict of Interest}

The authors declare that no conflicts exist.

\section{Financial Disclosure}

The authors declared no financial support.

\section{References}

[1] Atagun M, Balaban O, Atagun Z, Elagoz M, Ozpolat A. Caregiver Burden in Chronic Diseases. Psikiyatride Guncel Yaklasimlar - Current Approaches in Psychiatry. 2011;3(3):513-552. Available from: https://doi.org/10.5455/cap.20110323

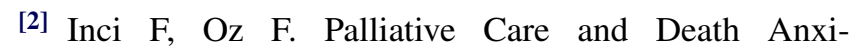
ety. Psikiyatride Guncel Yaklasimlar - Current Approaches in Psychiatry. 2012;4(2):178-187. Available from: https://doi.org/10.5455/cap.20120411

[3] Demir M. Palliative Care Ethics. Turkish Journal of Medical and Surgical Intensive Care. 2016 Oct 21;7(2):62-66. Available from: https://doi.org/10.5152/dcbybd.2016.1202 


\section{Determination of Caregiver Burden and Social Support Levels among Caregivers Providing Care for Patients \\ Hospitalized in Palliative Care Clinics - 6/7}

[4] Görgülü Ü, Akdemir N. İleri evre kanser hastalarına bakım verenlerin yorgunluk ve uyku kalitesinin değerlendirilmesi. Genel Tip Dergisi. 2010;20(4):125-132. Available from: http://geneltip.org/upload/sayi/66/GTD-00528.pdf

[5] Yilmaz DU, Sar1 D. The Investigation of The Relationship Between The Sleep Quality and Fatigue Levels of Caregivers Whose Patients With Chronic Disease. Anadolu Hemşirelik ve Sağlık Bilimleri Dergisi. 2017;20(2):90-98. Available from: https://dergipark.org.tr/

[6] Chan K-Y, Chan M-L. Enhanced psychosocial support as important component of neuro-palliative service. Annals of Palliative Medicine. 2018 Jul;7(3):355-358. Available from: https://doi.org/10.21037/apm.2017.08.19

[7] Aşiret G, Kapucu S. Care burden of the patient relatives who take care of the patients with stroke. Hemşirelikte Araştırma Geliştirme Dergisi. 2012;14(2):73-80. Available from: https://dergipark.org.tr/

[8] Eyigör S. General rehabilitation principles, quality of life and outcome assessment in patients with stroke. Turk J Phys Med Rehab. 2007; 53(Suppl 1):19-25. Available from: http://www.ftrdergisi.com/abstract.php?id=3213

[9] Palacio G C, Krikorian A, Gómez-Romero MJ, Limonero JT. Resilience in Caregivers: A Systematic Review. American Journal of Hospice and Palliative Medicine ${ }^{\circledR}$. 2019 Dec 13;37(8):648-658. Available from: https://doi.org/10.1177/1049909119893977

[10] Budak S. Palyatif bakım alan peg(perkütan endoskopik gastrostomi) ve ng(nazogastrik)' li hastalara bakım verenlerin bakım yükü ve yaşam kalitesinin incelenmesi [Yüksek Lisans Tezi]. Balıkesir:Balıkesir Üniversitesi; 2019.

[11] Küçükoğlu E. Kemoterapi alan hastaların bakım verenlerinin karşılanmamış gereksinimleri, bakım yükü, anksiyete ve depresyon düzeyleri [Yüksek Lisans Tezi]. Ankara: Hacettepe Üniversitesi; 2019.

[12] Bıçkı A. Erişkin yoğun bakım ünitesinden taburcu olacak hastaların bakım vericilerine yönelik "planlı taburculuk eğitiminin" güvenli hasta bakımına ve bakım yüküne etkisi [Yüksek Lisans Tezi]. İstanbul:Marmara Üniversitesi; 2018.

[13] Karakurt P, Ünsal A,Tanriverdi D. Evaluation of care burden and quality of life of caregivers of patients with stroke. International Journal of Caring Sciences. 2018;11(1):529-542. Available from: http://www.internationaljournalofcaringsciences.org/

[14] Yıldız E, Dedeli Ö, Çınar Pakyüz S. Evaluation of care burden and quality of life among family caregivers of patients with cancer. HEAD. 2016;13(3):216-225. Available from: https://doi.org/10.5222/HEAD.2016.216
[15] Doğru T. Dahiliye kliniklerinde yatan hastaların yakınlarının bakım yükü ve psikometrik özelliklerinin değerlendirilmesi [Yüksek Lisans Tezi]. Sakarya:Sakarya Üniversitesi;2019.

[16] Gündüz F. Kanserli hasta ve bakım verenlerinin algıladıkları sosyal destek ile umutsuzluk düzeyleri arasındaki ilişkinin belirlenmesi [Yüksek Lisans Tezi]. Aydın:Adnan Menderes Üniversitesi;2019.

[17] Bıçak D. Kanserli hasta ve bakım verenlerin algıladıkları sosyal destek ile yaşam kaliteleri arasındaki ilişkinin belirlenmesi [Yüksek Lisans Tezi]. Malatya:İnönü Üniversitesi;2016.

[18] Steigleder T, Kollmar R, Ostgathe C. Palliative Care for Stroke Patients and Their Families: Barriers for Implementation. Frontiers in Neurology. 2019 Mar 6;10:164. Available from: https://doi.org/10.3389/fneur.2019.00164

[19] Zarit SH, Reever KE, Bach-Peterson J. Relatives of the Impaired Elderly: Correlates of Feelings of Burden. The Gerontologist. 1980 Dec 1;20(6):649-655. Available from: https://doi.org/10.1093/geront/20.6.649

[20] İnci FH, Erdem M. Bakım verme yükü ölçeğinin Türkçeye uyarlanması geçerlilik ve güvenilirliği. Atatürk Üniversitesi Hemşirelik Yüksekokulu Dergisi. 2008;11(4):85-95. Available from: https://dergipark.org.tr/

[21] Zimet GD, Dahlem NW, Zimet SG, Farley GK. The Multidimensional Scale of Perceived Social Support. Journal of Personality Assessment. 1988 Mar;52(1):30-41. Available from: https://doi.org/10.1207/s15327752jpa5201_2

[22] Eker D, Arkar H. Çok boyutlu algılanan sosyal destek ölçeğinin faktör yapısı, geçerlik ve güvenirliği. Türk Psikiyatri Dergisi. 1995;10(34):45-55.

[23] Şener A, Aydoğan A, Koç Z. Palyatif bakım ünitesinde yatan hastaların bakımından sorumlu hasta yakınlarının bakım yükleri ile yaşam doyumlarının belirlenmesi. In: International Participatory Palliative Care and Hospice Congress. Istanbul; 2018. p. 46.

[24] Yıldızeli ŞO. İleri ve son evre akciğer hastalığına ikincil solunum yetmezliği olan hastalarda bakim verici yükü ve depresyon ilişkisi. In: International Participatory Palliative Care and Hospice Congress. Istanbul; 2018. p. 76.

[25] Palacio Gonzalez C, Roman-Calderón JP, Limonero JT. The relationship between positive aspects of caring, anxiety and depression in the caregivers of cancer patients: The mediational role of burden. European Journal of Cancer Care. 2020 Oct 10:76. Available from: https://doi.org/10.1111/ecc.13346 
[26] Öner Öİ. Onkoloji hastalarına bakım verenlerin bakım verme yükü ve algıladıkları sosyal desteğin incelenmesi [Yüksek Lisans Tezi]. Elazığ:Fırat Üniversitesi; 2012.

[27] Zavagli V, Raccichini M, Ercolani G, Franchini L, Varani S, Pannuti R. Care for Carers: an Investigation on Family Caregivers' Needs, Tasks, and Experiences. Transl Med UniSa. 2019;19:54-59. Available from: http://www.ncbi.nlm.nih.gov/pubmed/31360668

[28] Gür SC. Kanserli hastalara bakım veren bireylerin bakım yükü, yaşam kalitesi ve etkileyen faktörlerin incelenmesi [Yüksek Lisans Tezi]. Şanlıurfa:Harran Üniversitesi; 2018.

[29] Taşkın Egici M, Kök Can M, Toprak D, Öztürk GZ, Esen ES, Özen B, et al. Burden and Burnout of Caregivers Whose Patients Treated at the Palliative Care Center. Journal of Academic Research In Nursing. 2019;5(2):123-131. Available from: https://doi.org/10.5222/jaren.2019.38247

[30] Tanrıkulu S. Evinde bir aile üyesine bakım veren kadınların bakım verme yüklerinin incelenmesi [Yüksek Lisans Tezi]. Ankara: Başkent Üniversitesi;2019.
[31] Ejem D, Bauldry S, Bakitas M, Drentea P. Caregiver Burden, Care Recipient Depressive Symptomology, and Social Exchange. Journal of Palliative Care. 2018 Mar 7;33(2):100-108. Available from: https://doi.org/10.1177/0825859718758120

[32] Delalibera M, Barbosa A, Leal I. Circunstâncias e consequências do cuidar: caracterização do cuidador familiar em cuidados paliativos. Ciência \& Saúde Coletiva. 2018 Apr;23(4):1105-1117. Available from: https://doi.org/10.1590/1413-81232018234.12902016

[33] Arias-Rojas M, Carreño-Moreno S, Arias-Quiroz N. The "PalliActive Caregivers" Intervention for Caregivers of Patients With Cancer in Palliative Care. Journal of Hospice \& Palliative Nursing [Internet]. 2020 Oct 12;22(6):495-503. Available from: https://doi.org/10.1097/NJH.0000000000000696

Received: 2020-10-09

Revised: $2020-11-19$

Accepted: 2020-11-23 